\title{
Devil's Thorn (Emex spinosa (L.) Campd.) Response to Tribenuron-methyl and 2,4-D in Ouazzane Region of Morocco
}

\author{
Hajjaj B., \\ El Oualkadi A., \\ Tantaoui H., \\ Chentouf M., \\ Regional Agricultural Research Center of Tangier, Morocco
}

\begin{abstract}
A soft wheat weed control trial was conducted during the 2016-2017 growing season. The aim of this study is to investigate the effect of two postemergence herbicides Tribenuron-methyl and 2,4 D on Emex spinosa infestation in a soft wheat crop. Treatments consist on two Tribenuron-methyl rates of application and two 2,4-D rates of application. The experimental design was a random block with tree repetitions and observations were made 60 days after application of herbicides. Results showed that treatment with Tribenuron-methyl at $9.50 \mathrm{~g} / \mathrm{ha}$ and $14.25 \mathrm{~g} / \mathrm{ha}$ widely decrease E. spinosa infestations. Tribenuron-methyl at $9.50 \mathrm{~g} / \mathrm{ha}$ recorded $87.8 \%, 86.1 \%$ and $90.5 \%$ respectively on E. spinosa density reduction, E. spinosa height reduction, and $\mathrm{E}$. spinosa dry biomass reduction. Tribenuron-methyl at $14.25 \mathrm{~g} / \mathrm{ha}$ recorded $96.3 \%, 95.5 \%$ and $98.7 \%$ respectively on E. spinosa density reduction, E. spinosa height reduction, and E. spinosa dry biomass reduction. 2,4 D at $400 \mathrm{~g} / \mathrm{ha}$ and $600 \mathrm{~g} / \mathrm{ha}$ recorded the lowest efficacies that did not exceed $75.2 \%$ in all observed parameters.
\end{abstract}

Keywords: Emex spinosa, Soft wheat, Herbicide, Tribenuron-methyl, 2,4-D

\section{Introduction}

Cereals are important crops in the farming systems of Morocco (Karrou \& al., 2008). They are major food and feed crops. Total annual cereal production is estimated at 5 million tons per year. It covers an annual area of 5.3 million hectares (Mapmdref, 2019). Weeds are a serious constraint to cereal productivity in Morocco (Bouhache, 2017). In fact, weeds compete with crops using water, nutrients and lights and led to reduced crop yield (Spitters 
\& Van Den Bergh, 1982; Zimadahl \& El Brahli, 1992; Boutahar, 1994; Taleb 1996, Bouhache, 2007; Bouhache, 2017). E. spinosa (L.) Campd. (Devil's thorn) is a noxious weed to cereal crops (Hajjaj, 2010). It is an annual weed that belongs to Polygonaceae family. It has a large taproot. Stems usually lying down, ribbed up to $80 \mathrm{~cm}$. Leaves are alternate with triangular shape. Basal flowers are female and tops generally male (Boulet \& al., 1991). The fruit is an achene with stiff spines due to modified lobes of the perianth (Valdés \& al., 2002). Nitrophile plant, grazed by animals before the appearance of fruit (Tanji, 2005).Tribenuron-methyl is a cereal postemergence herbicide acting through the roots and foliage for the control of broadleaf weeds on wheat and barley. Tribenuron-methyl belong to sulfonylurea family that causes inhibition of acetolactate synthase ALS (acetohydroxyacid synthase AHAS). This enzyme is present in plant and micro-organisms, but not in animals (Blair \& Martin, 1988; Brown, 1990). Inhibition of the activity of ALS leads to inhibition of synthesis of essential branched-chain amino acids, which causes inhibition of cell division (Ezzahiri, 2017). Corp selectivity of sulfonylurea consists in a detoxification by hydroxylation and conjugation to glucose (Ray, 1984; Rost, 1984; Van Dyck \& LaRossa, 1986). Advantages of sulfonylureas herbicides are relatively low amount of herbicide used for weed control with low toxicity (Ezzahiri, 2017). 2,4 D herbicide is a post-emergence herbicide acting through the foliage for the control of broadleaf weeds on wheat and barley. 2,4-D is a member of Phenoxy-carboxylic-acid Family. 2,4-D is an "auxin mimic" or synthetic auxin. This type of herbicide kills weeds by mimicking the plant growth hormone auxin, and when applied at effective doses, causes uncontrolled and disorganized plant growth and the tissues of the plant are damaged, which leads to plant death. (Tu \& al., 2001). In tolerant monocots such as wheat and barley, metabolism occurs mainly through hydroxylation (Sterling \& Hall, 1997). In Morocco, more than 50\% of anti-dicot herbicides are phytohormone products $(2,4 \mathrm{D}, \mathrm{MCPA}$ and Dicamba) that can be used at an advanced stage of wheat. ALS inhibitor herbicides are the second category of herbicides (Bouhache, 2017). E. spinosa has become a serious problem in cereal crops in Morocco (Hajjaj, 2010). Furthermore, infestations by $E$. spinosa in cereal crops may result in the refusal of the harvest of some farmers by Moroccan seed companies (Onssa, 2019). No studies have been conducted on chemical control of E. spinosa in the Ouazzane region. This study aims to evaluate different doses of Tribenuron-methyl and 2,4-D herbicides on $E$. spinosa infestation in soft wheat crop.

\section{Material and Methods}

A trial of chemical control of E. spinosa was conducted in Ouazzane region of Morocco during 2016-2017 growing season. The experimental 
design was a random block with tree repetitions. The distance between the blocks is 2 meters and the distance between plots was 1 meter. Each block contained 5 elementary plots, 4 plots of which are treated with the postemergence herbicides tested (Table 1) and one untreated control plot. The size of the elementary plots was $2 \mathrm{~m}$ x $5 \mathrm{~m}\left(10 \mathrm{~m}^{2}\right)$. Treatments were carried out on January 06, 2017 with Backpack herbicide sprayer with nozzle delivering a 3 bar jet. The spray volume per hectare is 200L. Treatments consist on two Tribenuron-methyl rates of application and two 2,4-D -ester butylglycol rates of application (Table 1).

Table 1: Applied herbicides in experimental site

\begin{tabular}{ccc}
\hline $\begin{array}{c}\text { Herbicide } \\
\text { treatments }\end{array}$ & $\begin{array}{c}\text { Herbicide active } \\
\text { ingredient }\end{array}$ & $\begin{array}{c}\text { rate of application } \\
\text { (g/hectare) }\end{array}$ \\
\hline Treatment 1 & Tribenuron-methyl & 9.50 \\
Treatment 2 & Tribenuron-methyl & 14.25 \\
Treatment 3 & 2,4-D & 400 \\
Treatment 4 & 2,4-D & 600 \\
& & \\
\hline
\end{tabular}

Observations were made 60 days after application of herbicides. Observations concerned Percentage of $E$. spinosa density reduction, height reduction and biomass reduction. $E$. spinosa density reduction percentage $=[E$. spinosa density in control plots $-E$. spinosa density in treated plots] x 100 / [E. spinosa density in control plots]. Calculation of the density at the experimental level of the plot was made by a quardat of one square meter. $E$. spinosa height reduction percentage $=[E$. spinosa height in control plots $-E$. spinosa height in treated plots] x $100 /$ [E. spinosa height in control plots]. E. spinosa dry biomass reduction percentage $=[E$. spinosa dry biomass weight in control plots - E. spinosa dry biomass weight in treated plots] x $100 /$ [E. spinosa dry biomass weight in control plots]. Calculation of dry E. spinosa biomass were made by collecting $E$. spinosa in each plot using a quardat of $1 \mathrm{~m} \times 1 \mathrm{~m}$. Samples were dried in a drying oven at $75^{\circ} \mathrm{C}$ for 48 hours. Then, dry plant material in each plot were weighed with a precision balance. Statistical analyzes were performed with SPSS software version 21.0 using the analysis of variance (ANOVA).The difference among treatment means was compared by Tukey's test at $\mathrm{p} \leq 0.05$.

\section{Results and Discussion}

\section{Effect on $\boldsymbol{E}$. spinosa density reduction}

Results in table 2 revealed that the best $E$. spinosa density reduction was obtained by Tribenuron-methyl at $9.50 \mathrm{~g} / \mathrm{ha}$ and Tribenuron-methyl at $14.25 \mathrm{~g} / \mathrm{ha}$ recording respectively $87.8 \%$ and $96.3 \%$ of $E$. spinosa density reduction. Contrariwise, 2,4-D at 400g/ha and 2,4-D at 600g/ha showed lower to medium efficacies that did not exceed $75.2 \%$ of $E$. spinosa density 
reduction. It is important to mention that there were no significant statistical differences on $E$. spinosa density reduction between Tribenuron-methyl at 9.50g/ha and Tribenuron-methyl at $14.25 \mathrm{~g} / \mathrm{ha}$ (Table 2).

Table 2: Effect on E. spinosa density reduction

\begin{tabular}{cc}
\hline Treatments & E. spinosa density reduction $(\%)$ \\
\hline Tribenuron-methyl at $9.50 \mathrm{~g} / \mathrm{ha}$ & $87.8 \mathrm{c}^{*}$ \\
Tribenuron-methyl at $14.25 \mathrm{~g} / \mathrm{ha}$ & $96.3 \mathrm{c}$ \\
2,4-D at $400 \mathrm{~g} / \mathrm{ha}$ & $51.5 \mathrm{a}$ \\
$2,4-\mathrm{D}$ at $600 \mathrm{~g} / \mathrm{ha}$ & $75.2 \mathrm{~b}$ \\
\hline$P \alpha=0.05$ & $<0,001$
\end{tabular}

*Significant differences within the same column and means followed by the same letter $d o$ not differ at $P \alpha \leq 0.05$ according to Tukey's test.

\section{Effect on $E$. spinosa height reduction}

Results in table 3 showed that the best E. spinosa height reduction was obtained by Tribenuron-methyl at $9.50 \mathrm{~g} / \mathrm{ha}$ and Tribenuron-methyl at $14.25 \mathrm{~g} / \mathrm{ha}$ recording respectively $86.1 \%$ and $95.5 \%$ of $E$. spinosa height reduction (Table 3). Concerning the effect of $2,4-\mathrm{D}$ at $400 \mathrm{~g} / \mathrm{ha}$ and $600 \mathrm{~g} / \mathrm{ha}$, data in Table 3 showed lower to medium efficacies that did not exceed $72.7 \%$ of E. spinosa height reduction. It is important to mention that there were no significant statistical differences on $E$. spinosa height reduction between Tribenuron-methyl at $9.50 \mathrm{~g} / \mathrm{ha}$ and Tribenuron-methyl at $14.25 \mathrm{~g} / \mathrm{ha}$ (Table 3 ). In fact, Tribenuron-methyl belong to sulfonylurea family which mode of action Inhibit the acetolactate synthase (ALS) a key enzyme in the biosynthesis of the branched-chain amino acids isoleucine, leucine, and valine (LaRossa \& Schloss, 1984). Enzyme Inhibition affects necessary protein synthesis. Therefore this affect plant growth and height, which is arrested within a few days before plant death.

\section{Effect on $E$. spinosa dry biomass reduction}

Data in Table 4 indicate that the best E. spinosa dry biomass reduction was achieved by Tribenuron-methyl at $9.50 \mathrm{~g} / \mathrm{ha}$ and Tribenuron-methyl at $14.25 \mathrm{~g} / \mathrm{ha}$ recording respectively $90.5 \%$ and $98.7 \%$ of $E$. spinosa dry biomass reduction. Concerning the effect of 2,4-D at $400 \mathrm{~g} / \mathrm{ha}$ and $600 \mathrm{~g} / \mathrm{ha}$, results showed lower to medium efficacies that did not exceed $63.8 \%$ of E. spinosa dry biomass reduction. It is important to mention that there were no significant statistical differences on E. spinosa dry biomass reduction between Tribenuron-methyl at $9.50 \mathrm{~g} / \mathrm{ha}$ and Tribenuron-methyl at $14.25 \mathrm{~g} / \mathrm{ha}$ (Table 4). These results are in line with those of Abouziena \& al. (2008) who reported that Tribenuron-methyl applied at $14.28 \mathrm{~g} / \mathrm{ha}$ resulted in marked reduction in the dry weight of E. spinosa when compared with unweeded treatments recording $93.5 \%$ of $E$. spinosa dry biomass reduction. Moreover, same authors 
reported that Tribenuron-methyl was better than hand weeding. This is because manual weeding eliminates only inter-rows weeds, while weeds located close to wheat plants are not controlled (Abouziena \& al., 2008).

Table 3: Effect on E. spinosa height reduction

\begin{tabular}{cc}
\hline Treatments & E. spinosa height reduction \\
\hline Tribenuron-methyl at $9.50 \mathrm{~g} / \mathrm{ha}$ & $86.1 \mathrm{~b}^{*}$ \\
Tribenuron-methyl at $14.25 \mathrm{~g} / \mathrm{ha}$ & $95.5 \mathrm{~b}$ \\
2,4-D at $400 \mathrm{~g} / \mathrm{ha}$ & $62.8 \mathrm{a}$ \\
$2,4-\mathrm{D}$ at $600 \mathrm{~g} / \mathrm{ha}$ & $72.7 \mathrm{a}$ \\
\hline$P \alpha=0.05$ & $<0,001$ \\
\hline
\end{tabular}

*Significant differences within the same column and means followed by the same letter do not differ at $P \alpha \leq 0.05$ according to Tukey's test.

Table 4: Effect on E. spinosa dry biomass reduction

\begin{tabular}{cc}
\hline Treatments & E. spinosa dry biomass reduction \\
\hline & \\
Tribenuron-methyl at $9.50 \mathrm{~g} / \mathrm{ha}$ & $90.5 \mathrm{~b}^{*}$ \\
& $98.7 \mathrm{~b}$ \\
Tribenuron-methyl at $14.25 \mathrm{~g} / \mathrm{ha}$ & $55.4 \mathrm{a}$ \\
$2,4-\mathrm{D}$ at $400 \mathrm{~g} / \mathrm{ha}$ & $63.8 \mathrm{a}$ \\
2,4-D at $600 \mathrm{~g} / \mathrm{ha}$ & $<0,001$ \\
\hline$P \alpha=0.05$ &
\end{tabular}

"Significant differences within the same column and means followed by the same letter do not differ at $P \alpha \leq 0.05$ according to Tukey's test.

\section{Conclusion}

This study has shown that the herbicide Tribenuron-methyl at $9.50 \mathrm{~g} / \mathrm{ha}$ and $14.25 \mathrm{~g} / \mathrm{ha}$ gave the best control of E. spinosa. However, statistical analysis revealed no significant differences between these two rates of application. 2,4D herbicide showed low to medium control of E. spinosa. Tribenuron-methyl at reduced rate of $9.50 \mathrm{~g} / \mathrm{ha}$ can be recommended to farmers in Ouazzane region when E. spinosa infestation is dominant. This study should be repeated with different herbicides with different modes of action to evaluate their effect on E. spinosa.

\section{Acknowledgments}

The authors are grateful to all technicians of ONCA Ouazzane for providing necessary facilities for conducting this research work.

\section{References:}

1. Abouziena H.F., Sharara Faida A.A \& El-desoki E.R. (2008). Efficacy of cultivar selectivity and weed control treatments on wheat yield and associated weeds in sandy soils. World Journal of Agricultural Sciences, 4 (3). Pages: 384-389. 
2. Blair A.M. \& Martin T.D. (1988). A review of the activity, fate and mode of action of sul-fonylurea herbicides. Pestic. Sci., 22. Pages: 195-219.

3. Bouhache M (2007). Désherbage chimique des céréales d'automne. Agiculture du Maghreb N²5. Pages : 57-62.

4. Bouhache M. 2017. Attouts et faiblesses des herbicides utilisables sur les céréales au Maroc. Agriculture du Maghreb N¹00. Pages: 9-19.

5. Boulet C., Bouhache M., Wahbi M. \& Taleb A. (1991). Les mauvaises herbes du Souss. Actes éditions, Institut Agronomique et Vétérinaire Hassan II, Rabat, 1991. 295p.

6. Boutahar K. (1994). Impact de la date de récolte et la présence des adventices sur les pertes en grain à la récolte des céréales. Al Awamia No85. Pages : 25-32.

7. Brown H.M. (1990). Mode of action, crop selectivity, and soil relations of the sulfonylureaherbicides. Pestic. Sci. N²9. Pages: 263-281.

8. Ezzahiri B., Bouhache M. \& Mihi M. (2017). Index Phytosanitaire Maroc, 304p.

9. Hajjaj B. (2010). Diagnostic de la situation du désherbage chimique des céréales et légumineuses dans la région de Sidi El Aidi (Chaouia) et Jemaa shaim (Abda). Proc. 7ème congés de l'Association Marocaine de Protection des Plantes. Pages : 357-364.

10. Karrou M., El Mourid M., Boutfirass M. \& El Gharous M. (2008). Opportunities for improving wheat water productivity in semi-arid areas of Morocco. Al Awamia N¹23-124. Pages: 19-37.

11. LaRossa, R.A., \& Schloss, J.V. (1984). The sulfonylurea herbicide sulfo-meturon methyl is an extremely potent and selective inhibitor of aceto-lactate synthase in Salmonella typhimurium. The journal of biological chemistry. Vol. 259, No 14, , Issue of July 25. Pages: 87538757.

12. Mapmdref (2019). Ministère de l'Agriculture, de la Pêche Maritime, du Développement Rural et des Eaux et Forêts, MAROC. Division des statistiques.

13. Onssa (2019). Office de Sécurité Sanitaire des Produits Alimentaires. http://www.onssa.gov.ma. 18/10/2019.

14. Ray T.B. (1984). Site of action of chlorsulfuron. Inhibition of valine and isoleucine biosynthesis in plants. Plant Physiol. No75: 827-831.

15. Rost T.L. (1984). The comparative cell cycle and metabolic effects of chemical treatments on root tip meristems. III. Chlorsulfuron. J. Plant Growth Reg. N³. Pages: 51-63.

16. Spitters C.J.T. \& Van Den Bergh J.P. (1982). Competition between crop and weeds: A system approach. In Biology and ecology of weeds. 
W. Holzner and N. Numata (eds.) 1982. Dr W. Junk Publishers, The Hague. ISBN 9061936829.

17. Sterling T.M. \& Hall J.C. (1997) Mechanism of action of natural auxins and the auxinic herbicides. In RM Roe, JD Burton, RJ Kuhr, eds, Herbicide Activity: Toxicology, Biochemistry and Molecular Biology. IOS Press, Amsterdam. Pages: 111-141

18. Taleb A. (1996). La flore adventice du Maroc. Caractérisation et importance économique. Bulletin de transfert de technologie en agriculture $\mathrm{N}^{\circ} 18$. Rabat-Maroc.

19. Tanji A. (2005). Adventices du blé et de l'orge au Maroc. INRA Editions, Rabat, 2005. 458p.

20. Tu M., Hurd C. \& Randall J.M. (2001). Weed Control Methods Handbook: Tools and Techniques for Use in Natural Areas., The Nature Conservancy, Wildland Invasive Species Team. Version April 2001.

21. Valdés B, Rejdali M., Achhal El Kadmiri A., Jury J. L. \& Montserrat J. M. (2002). Catalogue des plantes vasculaires du Nord du Maroc incluant des clés d'identification/Checklist of vascular plants of north Morocco with identification keys. Madrid: Consejo Superior de Investigaciones Científicas.

22. Van Dyk T.K. \& LaRossa R.A. (1986). Sensitivity of a Salmonella typhimurium aspC mutant to sulfometuronmethyl, a potent inhibitor of acetolactate synthase II. J. Bacteriol. N${ }^{\circ} 165$. Pages: 386-392.

23. Zimadahl R.L \& El Brahli A. (1992). Pertes occasionnées par les mauvaises herbes sur les céréales en zone semi-aride du Maroc occidental. Al Awamia N75. Pages : 53-62. 